\title{
Analysis on Whether World War III Will Happen in the Middle East From Historical Perspective
}

\author{
Jingyi $\mathrm{Ma}^{1, \mathrm{a}}$ \\ Shenzhen Middle school, Shenzhen, Guangdong Province, 518000, China \\ *Corresponding author. Email: angela@cas-harbour.org
}

\begin{abstract}
The academic research of World War III (hereinafter referred to as WW3) has been continued since several years ago. The Middle East, the major area where great power conflicts were performed, the center of national grievances, religious conflicts and cultural differences, is always the place most likely to trigger WW3. This article aims to analyze the Middle East issue from a historical perspective. By understanding the history of the Middle East and comparing and analyzing the current situation in the Middle East, this article draws conclusion that WW3 will not explore broadly from the Middle east to the whole world, but some regional wars will happen instead.
\end{abstract}

Key words: WW3, history, the Middle East

\section{INTRODUCTION}

The Middle East refers to the land located in the east of Europe, from the Mediterranean to the Persian Gulf. As the Middle East is the central region of Asia, Europe and Africa, this land tends to be measured by military rulers at any time. The religious conflicts occupied there for over 1,000 years. In this land, people of different races dispute, and people start wars because of hegemonic status, land and wealth. Foreign countries are eager to have a share in the Middle East, and Middle Eastern countries are eager to win a higher status. Terrorism and nuclear threats have also made the situation volatile. But simultaneously, the people on this land are extremely eager for peace, religiously believing in their religion, and hope to be respected.

Since the United States withdrew from the Iran nuclear agreement, conflicts in the Middle East have become increasingly acute. There are many opinions on whether the Third World War will break out in the Middle East. This article hopes to bring new perspectives and ideas to the basic discussion. The remainder of this paper is organized as follows. The second part will explain the complex history of the Middle East, and the third part will discuss the threats, and different causes of the conflict will be posed to the Middle East, and whether these threats will cause World War III.

\section{ANALYSIS ON THE HISTORY}

\subsection{Before WW2}

By the 18th century, Europeans achieved and maintained their military, political, and economic advantages over the Middle East. In fact, the great powers of that time-Britain, France, Russia, and Austria all looked down on the Middle
East. Arab nationalism raised before WW1. It refers to a kind of belief that all Arabs should be combined as an independent political community or a country and should own a combined government.

In August 1914, the Ottoman Empire decided to join the German side to participate in the WW1. The British response was to contact another Arab leader Hussein, they hoped to persuade him not to support the "jihad" of the Arabs against the Allies, and that he would lead the Arabs to oppose Ottoman domination. Under this premise happened the Hussein-McMahon communication.

British promised independence to the Arabs. But they also promised this land to other countries. The Russians, the French, the Italians, and the Greeks all wanted to share a portion of the Arab land. As a result, Britain, France, and Russia secretly concluded the so-called "Sex-Pickert Agreement" in May 1916. In addition, the British Cabinet would help Jews build their homeland in Palestine, as stated in the Belfort Declaration of November 2, 1917. This document supports the views of the Zionists and makes no mention of the political rights of non-Jewish indigenous peoples, namely Palestinians. In fact, more than nine-tenths of the Arabs settled on this land known as Palestine. This will be the beginning of the Arab-Israeli conflict that continues today.

\subsection{Conflict, War and Peace}

\subsubsection{Arab-Israeli conflict}

As a matter of fact, Arab and Israeli had a lot in common. Both of them speak Semitic languages, remembering the golden age in their respective history, and the political power, economic prosperity, as well as cultural prosperity of this era. Both nations believe that their political entities have been under external control for a long time after this 
period. The two major nations have long been conquered. Both nations are suffering because of their renunciation of their Divine Religion and acceptance of modern collective self-love ideology. They are full of skepticism, fearing that the whole world will be their enemy at a crisis. If it were not for historical prejudices, perhaps they could have been tolerant of each other[1].

Although Jews and Arabs demand Palestinians dating back hundreds of years, real struggles did not begin until the outbreak of World War I. During WW1 and WW2, the number of Jews in Palestine had soared, and conflicts between the parties had intensified. In order to find a peaceful solution to the satisfaction of all parties, Britain issued a policy document called the White Paper in 1939. After World War II, the violence in Palestine increased sharply and the US government began to pressure the United Kingdom. In February 1947, the British submitted the issue to the United Nations General Assembly, who adopted a divide-and-conquer program in 1947 and declared the Palestinian Jewish Control Zone is now an independent state of Israel in 1948.

From 1948 to 1949 , a war broke out between the newborn State of Israel and its Arab neighbors. The struggle was initially aimed at resistance from the Palestinians, later against British imperialism, and finally against the armies of the Arab nations. Victory leans towards Israel during Israel's war of independence. The United Nations tried to resolve the Arab-Israeli conflict. In January 1949, Ralph Benci held the negotiation. All Arab countries were in principle opposed to the 1947 division and the establishment of a Jewish state in Palestine, but the Arab leaders were actually trying to prevent each other.

Relatively peaceful time is not too long. On June 5, 1967, Israel launched a series of preemptive air strikes against its Arab neighbors. As a result, Israel defeated Egypt, Syria and Jordan in just six days. This is the "June War." One hour after the war began, Israel seized air control, then attacked the Sinai Peninsula, and occupied the entire peninsula after 4 days of fighting.

The war of 1967 wiped out the face of Arab nationalists. The cessation of the war on June 10 was that Israel had occupied the Gaza Strip, the Sinai Peninsula, the Jordan River and the Golan Heights, thereby expanding the land area to three times six days ago. About one million Arabs, mostly Palestinians, were already under Israeli rule. In June of the same year, Britain put forward a vague plan in the UN Security Council, namely, Resolution 242. Resolution 242, together with Hussein-McMahon Communications and the Belfort Declaration, has become a vague document that complicates the Arab-Israeli conflict.

The Yom Kippur War broke out on October 6, 1973. Egyptian President Sadat, who led the war, hoped to win chips for negotiation with Israel through the war. The war actually won the opportunity of peace for both of them. From January to May 1974, Kissinger shuttled between Jerusalem and Sadat's residence, and gradually drafted an "Disarmament Agreement". The agreement was provided for Israeli troops to withdraw from all areas on the west bank of the Suez Canal and to establish its ceasefire line about 20 miles east of the Suez Canal. A United Nations' observation force was admitted. In 1975, Kissinger once again promoted a new agreement on the Sinai with shuttle diplomacy, Israel and Egypt became more restrained after the war, and other Arab leaders failed to prevent Egypt's actions aimed at peace with Israel alone. After the Camp David war in 1979, it was thought that perhaps real Middle East peace was coming. Other places will become the new arena for the Arabs[2].

\subsubsection{Conflict in the Gulf}

Iraq is reluctant because of its second place in the Arab world. This perspective led to its conflict with Kuwait and Iran. A related diplomat point is that Iraq firmly believes that Western imperialism as a whole, especially Britain, seeks to thwart Iraq's development by creating an independent Emir State called "Kuwait." These conflicts developed into the Gulf war and the Iran-Iraq war[3].

Iraq qualified to stir up disputes. Iraq's area and population occupy the second place in the eastern Arab world. Utilizing its rich oil resources, it has economically constructed infrastructures suitable for industrial and agricultural development. It became stable and developed rapidly under Saddam Hussein's iron hand after 1970. The Soviet Union provided arms to the country and aligned itself with it. The fragmentation of its people has restrained its development to a certain extent.

During the Iran-Iraq war, both sides tried to use their own air power to destroy the other's oil pipelines, refineries, and civilians' will to fight. The army and civilians suffered more casualties than in any war in the modern Middle East, and the Iran-Iraq war lasted far longer than Iraqi people expected. The status quo countries favored Iraq, while the revolutionary countries supported Iran. The war ended without any negotiations and ended with Iraq's withdrawal, but the relationship between the two countries was only getting worse.

On August 2, 1990, Iraqi forces quickly invaded and occupied Kuwait. Many countries, including Egypt and Syria, have sent troops to form "alliances" with U.S. forces to participate in the officially named "Desert Shield Operation". The UN Security Council has passed a series of resolutions calling for Iraq to withdraw its troops unconditionally from Kuwait and to demand that other member states impose economic sanctions on Iraq, until Iraq unconditionally withdraws its troops. For Saddam and his supporters, these solemn demands were a direct challenge: they refused to withdraw.

The uncompromised between the two sides led to the outbreak of the war on January 17, 1991. Iraq and the Soviet Union made several proposals to withdraw troops from Kuwait, but Bush and his allies ignored the agreement and again demanded that Iraq comply with all UN Security Council resolutions. After Iraq's rejection, the coalition launched a ground offensive and expelled Iraqi troops from Kuwait within 100 hours. On February 27, 1991, the war ceased. 


\subsubsection{Terrorism}

Most of us started paying attention to the terrorism from the 11th of September, 2001. Actually, the terrorism appeared in the Middle East since years ago. The CIA's definition of terrorism is that individuals or groups use threats or violence to achieve the purpose of representing or opposing existing rules and authorities in order to shock or intimidate a group that is more widespread than its immediate victims. Certain attacks of a terrorist nature within the Middle East mainly threaten the territories of Iraq, Saudi Arabia, Yemen, Israel and the Palestinians. Compared to the infamous terrorist organization Al Qaeda, certain Middle Eastern and foreign governments' counter-terrorism initiatives threaten civilians and their governments even more. The main counterterrorism efforts are the United States, Britain, Israel, Palestine, as well as the Afghan and Iraqi governments. A typical example is the Iraq war. The U.S. invasion of Iraq is based on the possession of nuclear, biological and chemical weapons in Iraq. Its real purpose may be in the oil in Iraq or to change the Arab countries that oppose the United States. Another argument is that the United States hopes to overthrow the Saddam regime and replace it with another pro-American government. Terrorism also appeared in the conflict between Israel and Palestinian. Some Palestinians tied bombs to themselves and detonated themselves in discotheques, buses or crowded restaurants. As Palestinian violence escalated, Israel also begun to build a fence to prevent terrorism, a series of electronically monitored defense facilities, including concrete walls and barbed wire with barbed wire. This wall was not set up in accordance with the borders delineated by the United Nations before 1967, but in line with internationally recognized Palestinian lands. Israelis soon realized that because of the wall, terrorist attacks had even increased significantly. If for the Israelis, the self-destructing Palestinians were terrorist attackers and the Arabs saw Israeli tanks entering the main Palestinian street, bulldozers leveled the resident's suspected terrorist home, and helicopters fired into the densely populated city center Missile screen, the experts will doubt, who is the real representative of terrorism?

\subsubsection{Iranian nuclear issue}

From 2006, the Iranian nuclear issue has become the strongest barriers between the relationship of Iran and America. In fact, in 1980, after the Iran-Iraq war, diplomatic relations between the United States and Iran were declared broken. Iran announced in 2003 that it would refine nuclear fuel uranium. The document of Iranian nuclear issue was never be agreed till July 14, 2015, after long negotiations with the United States, the People's Republic of China, Russia, the United Kingdom, Germany, and France on the Iranian nuclear issue, Iran reached an agreement on restricting Iran's nuclear development and lifting sanctions on Iran. The comprehensive agreement is composed of the text and five technical annexes, which are related to nuclear, sanctions, civil nuclear energy cooperation, joint commission and implementation. Iran also agreed to limit uranium enrichment to no more than $3.67 \%$ within 15 years, and the United Nations ballistic missile sanctions on Iran would be retained for 8 years.

On May 8, 2018, the current U.S. President Trump announced that the United States would withdraw from the Iran nuclear agreement and will resume sanctions on Iran. On May 8, 2019, Iranian President Rouhani announced that he would stop fulfilling some of the commitments of the Iran nuclear agreement and refused to negotiate with the United States. On January 3, 2020, the U.S. launched a drone airstrike at the Baghdad International Airport in Iraq, assassinating the Islamic Revolutionary Guard and Holy Army commander Kassim Suleimani. On the evening of January 5, the Iranian government stated in a statement that Iran has suspended the implementation of restrictions on Iran in the fifth phase of the comprehensive agreement on the Iranian nuclear issue, and the solution of the Iranian issue will become the next challenge for the United Nations.

\section{DISCUSSION: TODAY AND TOMORROW}

The author has basically described the main historical plot of the Middle East. In exploration of the history of the Middle East, it is demonstrated that conflicts in the Middle East continue to increase over time. U.S. vs. Soviet Union, conflicts between oil producers and consumers, Islamist vs. secularists, Christians vs. Muslims, Shiites vs. Sunnis, Arabs vs. Israelis. The absolute peace of the Middle East may need hundreds of years to come. The authors of History of the Middle East, Mr. Arthur and Mr. Lawrence, listed the main reasons for conflicts in the Middle East. So next the author will analyze historically on why these conflicts did not trigger World War III.

Many words were used to introduce the history about the WW1 in the Middle East. This period had no straight relations with the situation today except one that so far, the transition from a community based on religion and observance of the Law of Divine Enlightenment to humankind has determined the law in order to improve its security and well-being in this world. Even more unfortunately, during the two world wars, the Arab-backed side always lost the war.

\subsection{Arab-Israel Conflict}

Will Arab-Israel conflict lead to the war? Throughout the entire process of the Arab-Israeli conflict, the trains of peace are constantly running, and this is not surprising. The ArabIsraeli conflict is a religious conflict, a social conflict, a territorial dispute, a military conflict, and even a terrorist conflict. It seems that Israel and the Arabs will always fight, and a third party will come to persuade, negotiate, sign a peace treaty, and fight again in a few days. The Arab-Israeli conflict may not be cured within a short period of time, but 
both sides are willing to trade to a certain degree for peaceful life and trade. Most times the Arabs compromise more. Where are Israel's borders? Raising this issue will cause quarrels and disputes. Although both sides have the support of their own interest groups, the major powers will not fight each other. They will be more inclined to use the Middle East to threaten each other and show their positions. So far, Palestine has not requested much. The homes of the homeless, and the relief of the indigent, need not be very fair and succinct but sufficient to manage the Palestinian government, and gradually reduce terrorist activities. On the other hand, what is the probability that Israel has signed peace agreements or trade relations with most Middle Eastern countries, Arab nationalism, or the Arabs formed an alliance, and attacked Israel together, as in the early Middle East war? very small. The Arabs have said that they are willing to accept "المصالحة" rather than", although both words mean peace, the former means to temporarily put down hatred, while the latter means reconciliation[7]. It is difficult for Israel and Palestine to shake hands, but neither has a shared obsession. This is probably the only lucky place in the Arab-Israeli conflict.

\subsection{The Gulf War Iran-Iraq War}

Next is about the Iran-Iraq war. Who is the boss of the Gulf region? This is indeed a headache. But this problem is not enough to cause World War III. As mentioned earlier, before the Iranian Revolution, Iran was a well-deserved police officer in the Gulf. Iraq hopes to snatch Iran's position when Iran is over. It is a good sign that the current Gulf region is under equilibrium. Europe has maintained peace for many years through balance of power. Germany broke the European balance of power and caused World War I. Will the Middle East repeat the same mistakes? It is difficult for the Middle East to develop into a country that has a large gap with other countries like Germany at the time. In addition, the Middle East is under a certain degree of manipulation and surveillance by the European Union, China, Britain, France, Russia, the United States and more[4]. When Iraq attacks Iran, it is subject to UN sanctions. The relatively simple oil industry in the Middle East has also become an effective means of burden and sanctions for war.

The Gulf War and the Iran-Iraq War above have one thing in common, that is, they are in a strong era. The era here refers to the then Iraqi leader Saddam and the backward Iraqi government structure. In fact, the political system of Iraq at that time was highly specialized, and the state controlled Iraq's main industries, all educational institutions, and propaganda tools. Saddam Hussein's personal worship reached its peak, and no one dared to openly oppose his policies. Immediate executions without trial, torture and long prison sentences were common. Helpers before Saddam took power, most of the officers and ministers were removed, exiled, or forced to retire. The Arab-equipped army is under Saddam's control. All this has led to Iraqi interests being equated with personal interests in Saddam's eyes, which has also led to fickle policy. But there is another reason for the Gulf War. The wealth gap between Kuwait's wealth and other Arabs is too large. The war caused by economic problems. The Gulf War raises another question: Will economic problems lead to World War III? This is the subject of economists. I will say that economic problems in the Middle East will hardly lead to World War III. Inflation in the Middle East was particularly apparent right after the end of World War II. In the fourth quarter of 2018, total economic growth in the Middle East and North Africa was $1.9 \%$. Prior to this, economic growth in the Middle East was rapid, and economic growth will slow in 2019[5]. Private consumption will benefit from lower tax burdens and still a favorable financial environment, and new projects related to natural gas and oil should boost fixed investment growth.

\subsection{Terrorism and Nuclear}

Will terrorism cause World War III? Terrorism is a problem confronted by all nations and peoples, not the cause of conflict between nations. Was the real cause of the Iraq war terrorism? The Iraq war is a typical example of foreign countries using the Middle East for their own interests. From terrorism we can extend to another question: Will cultural antagonism in the Middle East lead to World War III? The opposition of religions and the differences of civilizations. Nationalism in the Middle East is an important force in promoting social and cultural changes in the Middle East, but the cultural integration process in the Middle East is not smooth. From the outside, the constraints of the relatively backward socio-economic development in the Middle East, the dilemma of political salvation and cultural enlightenment, and the opposition between Islamic culture and nationalism have determined that the social and cultural changes in the Middle East are very difficult. Fortunately, cultural integration in the Middle East is still continuing[6]. Internal demand and external promotion have determined that the Middle East can only get out of the predicament under the premise of cultural integration. But this process of cultural integration is long and difficult. We will not pretend that the cultural integration of the Middle East will be smooth, but to a certain extent, cultural antagonism will not cause World War III. Regional battles will continue to occur intermittently, such as between Shiites and Sunnis, and between Arabs and Israelis. But this will remain a regional battle on a high probability.

From the above, it can be concluded that unless the big powers, such as China or the United States, are willing to launch World War III, the possibility of the Middle East alone is very small. But once the great powers hope to obtain more attractive benefits than war through the war, it must be said that the Middle East will be the best choice for the beginning of the war. As mentioned above, the major powers use the Middle East to achieve their own interests. Nuclear war is the loudest of the possibilities of the Third World War. The Iranian nuclear crisis will bring back the possibility of a gas war in 2020 . Will nations use nuclear weapons with each other? will not. Once there was a question and answer, what kind of weapons would countries 
use if World War III broke out? Einstein replied: "I don't know what weapons were used in World War III, but I know that humans used them in World War IV[7]. It must be stones and sticks, because human civilization has been destroyed in the nuclear war of World War III. "So far, Iran has the ability to produce devastating weapons with great possibility, although Its accuracy and range may need to be improved, but large-scale weapons do become increasingly concentrated in chaotic and vulnerable countries. So far, there are at least 8 countries in the world with nuclear weapons. This is official data. What other countries have the ability to produce nuclear weapons in a short period of time? We do not know. For the big powers, they are willing to go to war only if the damage caused by nuclear missiles is less than the benefits brought by nuclear war. What are the possible losses from nuclear missile strikes? The first is the destruction of cities, environmental problems, casualties, refugees, and the possible intensification of war and conflicts, which may doubt the legitimacy of the country, sharply increase the number of terrorists, stimulate the hatred of the people against the enemy in peaceful times, etc. Wait. Once a nuclear bomb is thrown out, the possibility of war outbreaks will continue to increase, and the possibility of global war outbreaks will also increase. The tempting benefits brought by the Middle East are not as great as those brought about by nuclear war. The inevitable result of the outbreak of nuclear war will be a sharp decline in the number of human beings.

\section{CONCLUSION}

Will WW3 break out in the Middle East? This problem have been analyzed from Arab-Israeli conflict, clash of civilizations, economic issues, ethnic conflicts, terrorism, regime structure and nuclear war. It is fortunate that we found although we will not embrace a peaceful Middle East in the short future, we will also not face to the WW3. A sentence from the book History of the Middle East would be great to write here, where we can learn many things about Middle Easterners, such as hospitality, generosity, strong family bonds, and a genuine understanding of the needs and feelings of others. But the author estimate that the conflict will continue. Don't expect to find a simple solution. It is important to pay attention to the declared interests and concerns of various parties in various disputes and conflicts in this area, and to explore the unknown hopes and fears of all parties. The content of this article's analysis and the possibility of the outbreak of the Third World War are just personal views. The future of the Middle East will eventually give the answer.

\section{ACKNOWLEDGMENT}

First and foremost, I would like to show my deepest gratitude to my teachers and professors in my university, who have provided me with valuable guidance in every stage of the writing of this thesis. Further, I would like to thank all my friends and roommates for their encouragement and support. Without all their enlightening instruction and impressive kindness, I could not have completed my thesis.

\section{REFERENCES}

[1] Godschmidt Jr., Lawrence Davidson. A Concise History Of The Middle East. [A]. Arrangement with Westvies Press, A Member of Perseus Book Group, 2019.

[2] Wang Jinglie. "The Historical Origin, Evolution and Development Trend of the Arab-Israeli Conflict". Journal of the Graduate School of the Chinese Academy of Social Sciences. 1994, (3).

[3] Wan Guang. "New Power and New Pattern in the Middle East Today". West Asia and Africa. 2018, (1).

[4] JIN Liangxiang. "The Middle East Regional Geopolitics at the Beginning of the 21st Century". Arab World Studies, 2013(2):29-39.

[5] Economic and Commercial Office of the Embassy in Jordan. 2020, Jun 23. "2019: A Brief Account of the Economic Situation in the Middle East and North Africa". Ministry of Commerce of The People's Republic Of China, [Online] Available: http: //www.mofcom. gov.cn/[Accessed on March 10, 2019]

[6] Tian Wenlin. "Middle Eastern Nationalism and Social Cultural Changes in the Middle East". World Nations. 2002, (5).

[7] Sheng Shiliang. "Can a Nuclear-Free World Really Be Realized?" Current Affairs Report University Student Edition. 2010, (1). 